\title{
ORIGINAL \\ The fate of hypertrophic chondrocytes of the rat mandibular condyle in Strontium Rickets
}

\author{
Noriaki Saburi, Nozomu Taguchi, Toshiro Kaneda and Takeshi Hoshino* \\ Department of Oral Surgery (Chief : Prof. T. Kaneda) \\ Anatomy* \\ (Chief : Prof. T. Hoshino) \\ Nagoya University School of Medicine, Showa-ku, Nagoya, 466, Japan
}

[Accepted for publication: November 20, 1986]

Key words : Strontium Rickets / endochondral ossification / hypertrophic chondrocyte

\begin{abstract}
In the mandibular condyle of young rats, strontium rickets was induced by a diet in which $2.2 \% \mathrm{SrCO}_{3}$ was substituted for calcium salt in a standard diet. The main morphological changes which were characteristic of strontium rickets were a small condyle, an enlarged ramus, an expansion of the hypertrophic cell zone, and the formation of osteoid tissue. By light and electron microscopy, mitotic figures were often observed in the hypertrophic chondrocytes located in the transitional area between the hypertrophic cell zone and osteoid tissue. In addition, the cells within the lacunae in the same area, showed a series of cytological features suggesting a transition of hypertrophic cells to osteoblast-like cells and further to osteocyte-like cells, which were involved in the formation of osteoid tissue. These findings strongly suggest that in strontium rickets the hypertrophic chondrocytes do not degenerate, but can transform into osteogenic cells directly or after mitotic division. In the mandibular condyle of control rats which were given a standard diet containing $1.5 \% \mathrm{CaCO}_{3}$, many hypertrophic chondrocytes showed their activity until their lacunae were eroded by the invasion of capillaries. Although the further fate of these surviving chondrocytes has not been confirmed yet, our findings contradict the generally accepted concept that hypertrophic chondrocytes ultimately die during the process of endochondral ossification.
\end{abstract}

\section{Introduction}

The mandibular condyle, like other long bones, grows through the process of endochondral ossification. The chondrocytes differentiate from the immature cells of the proliferating cell zone. Advancing toward the ossification front, they mature and become hypertrophied. It has generally been accepted that these hypertrophic chondrocytes are finally differentiated cells which ultimately degenerate as they reach the ossification front $^{1-6)}$. A few investigators ${ }^{7-10)}$, however, have demonstrated that some hypertrophic chon. drocytes maintain their activity and survive beyond the ossification front. In the mandibular condyle, histochemical, ultrastructural and autoradiographic studies ${ }^{11-14}$ have also shown viability of hypertrophic chondrocytes, and a transformation of these cells into osteogenic cells was suggested. These findings have thrown serious doubts on the accepted concept that the hypertrophic chondrocytes ultimately degenerate. However, conclusive morphological evidence for such a transformation has not been presented.

During the course of ultrastructural studies on the mandibular condyle of the rat in experimentally induced strontium rickets, we observed mitotic cell divisions in hypertrophic chondrocytes and their morphological changes indicating a series of transition into osteoblast- and osteocyte-like cells which were involved in the formation of bone-like matrix. Therefore, in the present study we report the ultrastructure of these cells and their matrix, and discuss the fate of hypertrophic chondrocytes in endochondral ossification. 
Table 1 Composition of diets

\begin{tabular}{lcc}
\hline & $\begin{array}{r}\text { Control } \\
\text { diet }(\%)\end{array}$ & $\begin{array}{c}\mathrm{Sr} \\
\text { diet }(\%)\end{array}$ \\
\hline Corn starch & 39.478 & 38.778 \\
Milk-casein & 25.000 & 25.000 \\
$\alpha$-starch & 10.000 & 10.000 \\
Cellulose powder & 8.000 & 8.000 \\
Linoleic salad oil & 6.000 & 6.000 \\
Granulated sugar & 5.000 & 5.000 \\
Vitamin mixture* & 2.000 & 2.000 \\
$\mathrm{CaCO}_{3}$ & 1.500 & 0.000 \\
$\mathrm{SrCO}_{3}$ & 0.000 & 2.200 \\
$\mathrm{KH}_{2} \mathrm{PO}_{4}$ & 1.543 & 1.543 \\
$\mathrm{NaH}_{2} \mathrm{PO}$ & 0.561 & 0.561 \\
$\mathrm{NaCl}_{4}$ & 0.280 & 0.280 \\
$\mathrm{Fe}_{4} \mathrm{citrate}$ & 0.191 & 0.191 \\
$\mathrm{MgSO}_{4}$ & 0.430 & 0.430 \\
$\mathrm{ZnCO}_{3}$ & 0.007 & 0.007 \\
$\mathrm{MnSO}_{4} \cdot 4 \mathrm{H}_{2} \mathrm{O}$ & 0.007 & 0.007 \\
$\mathrm{CuSO}_{4} \cdot 5 \mathrm{H}_{2} \mathrm{O}$ & 0.002 & 0.002 \\
$\mathrm{KI}$ & 0.001 & 0.001 \\
\hline
\end{tabular}

* Vitamin mixture $(/ 100 \mathrm{~g}$ diet $)$

$\begin{array}{llr}\text { Vitamin } & \text { A } & 1000 \mathrm{IU} \\ & \mathrm{D}_{3} & 200 \mathrm{IU} \\ & \mathrm{B}_{1} & 2.4 \mathrm{mg} \\ & \mathrm{B}_{2} & 8.0 \mathrm{mg} \\ & \mathrm{B}_{6} & 1.6 \mathrm{mg} \\ & \mathrm{B}_{12} & 0.001 \mathrm{mg} \\ & \mathrm{C} & 60.0 \mathrm{mg} \\ & \mathrm{E} & 10.0 \mathrm{mg} \\ \quad \mathrm{K}_{3} & 10.4 \mathrm{mg} \\ \text { Biotin } & 0.04 \mathrm{mg} \\ \text { Folic acid } & 0.4 \mathrm{mg} \\ \text { Niacin } & 12.0 \mathrm{mg} \\ \text { Inositol } & 12.0 \mathrm{mg} \\ \text { Cholin-Cl } & 400.0 \mathrm{mg} \\ \text { Aminobenzoic acid } & 10.0 \mathrm{mg}\end{array}$

\section{Materials and Methods}

Twenty four male rats of Wistar strain, aged 3 weeks and weighing about $50 \mathrm{~g}$, were divided into two groups. One group was fed with a well-balanced, powdered diet containing $1.5 \% \mathrm{CaCO}_{3}$ (control group), and the other with a powdered diet in which $2.2 \% \mathrm{SrCO}_{3}$ was substituted for $1.5 \% \mathrm{CaCO}_{3}$ ( $\mathrm{Sr}$ group) (Table 1). Deionized water was given to all rats during the experimental period. After 3 weeks (aged 6 weeks), mandibular condyles were removed under ether anesthesia.
They were immediately cut in the frontal plane (parallel to the long axis of the ramus) at about $1 \mathrm{~mm}$ thick, and fixed over night in a fixative containing $2 \%$ paraformaldehyde and $2.5 \%$ glutaraldehyde in $0.05 \mathrm{M}$ phosphate buffer $(\mathrm{pH} 7.4)$ at $4{ }^{\circ} \mathrm{C}$. Specimens were decalcified with $0.5 \mathrm{M}$ EDTA-2 $\mathrm{Na}$ solution ( $\mathrm{pH}$ $7.4,4{ }^{\circ} \mathrm{C}$ ) for 5 days and fixed with $1 \%$ osmium tetroxide in $0.1 \mathrm{M}$ phosphate buffer for 2 hours at $4{ }^{\circ} \mathrm{C}$. They were dehydrated with ascending grades of ethanol and embedded in Quetol 812. Sections were cut in the frontal plane of the mandibular condyle using a glass knife or a diamond knife on a Porter-Blum MT-1 ultramicrotome. Semithin sections about $1 \mu \mathrm{m}$ thick were stained with $1.0 \%$ toluidine blue for light microscopic observations. Ultrathin sections were stained with uranyl acetate and lead citrate, and examined with an Akashi LEM 2000 or JEOL 100 CX electron microscope.

\section{Results}

In the $\mathrm{Sr}$ group, the mandibular condyle was smaller as compared with that of the control group, while the mandibular ramus was enlarged to be thicker than the width of its condyle. These histological changes were the same as those previously observed ${ }^{15}$. In the control group (Fig. 1 a), the fibrous zone, the proliferating cell zone, the mature cell zone, and the hypertrophic cell zone were differentiated in that order from the articular surface, but in the Sr group (Fig. $1 \mathrm{~b}$ ), the mature cell zone has almost disappeared. The hypertrophic cell zone of $\mathrm{Sr}$ group extended deep into the central part of the ramus, and was surrounded laterally by osteoid tissue with a gradual transition between both tissues. The primary spongiosa was not seen. Capillaries originating from the perichondrium, invaded the osteoid tissue. Only a small number of osteoblast-like cells were observed around the capillaries. The matrix of the hypertrophic cell zone showed an intense metachromasia with toluidine blue. The metachromasia faded gradually from the transitional border into the osteoid tissue. In some hypertrophic cells, degenerative appearances such as pyknosis or decomposition of the nucleus, and clearness of the cytoplasm could 


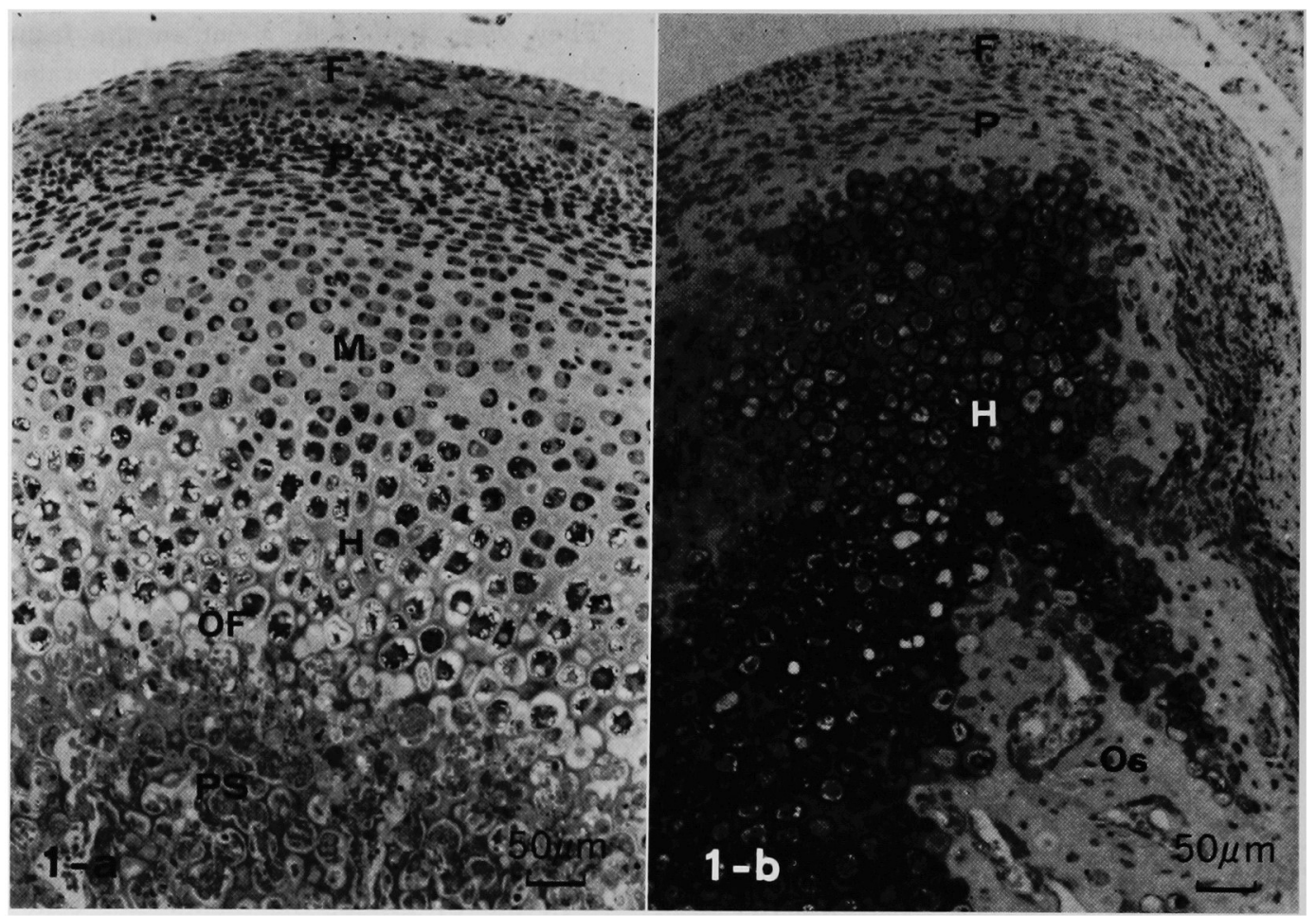

Fig. 1 Photomicrographs of the midfrontal plane of the mandibular condyle. Semithin section stained with toluidine blue.

a : Control group: Fibrous zone (F), proliferating cell zone (P), mature cell zone (M), and hypertrophic cell zone $(\mathrm{H})$ can be clearly differentiated. OF=Ossification front. $\mathrm{PS}=$ primary spongiosa. $\times 125$

b : Sr group : Proliferating zone $(\mathrm{P})$ is neighboured with hypertrophic cell zone $(\mathrm{H})$, which extends into the ramus and is surrounded laterally by osteoid tissue (Os). F=fibrous zone. $\times 125$

be found. However, many of the cells, having a vesicular nucleus, did not show any degenerative appearances (Fig. 2).

In the transitional area between hypertrophic cell zone and osteoid tissue, where the metachromasia of the matrix was fading, mitotic figures were often found in the cells located within the lacunae (Fig. 3 a, b). These lacunae were surrounded by a continuous wall of matrix and separated from the perivascular space of the invading capillaries. The mitotic cells had short cytoplasmic processes. There were chromosomes in the central part of the cell. In the peripheral part of the cytoplasm, a small amount of free ribosomes, rER of smaller sizes, mitochondria, and lysosome-like bodies were scattered. An extracellular space was found around the cell within the lacuna, where a small amount of filamentous structure, and small dense granules were present. In the cartilage matrix around the lacunae in which the mitotic cells were present, there were matrix fibrils without any distinct bandings and matrix granules scattered among the fibrils.

Within the lacunae in the same area, there were hypertrophic cells which showed a series of development towards the activity of protein secretion-from a cytoplasm with only a few profiles of rER of smaller size to that of osteoblast-like cells with abundant large rER and prominent Golgi complexes (Fig. 4, 5). These cells had an increasing amount of thick collagen fibrils with distinct D-periodicity in the matrix closely surrounding their cell body (Fig. 6). The collagen fibrils were 95.4 \pm $27.5 \mathrm{~nm}$ in diameter and irregular in cr.sssectional profile. Occasionally two or more 


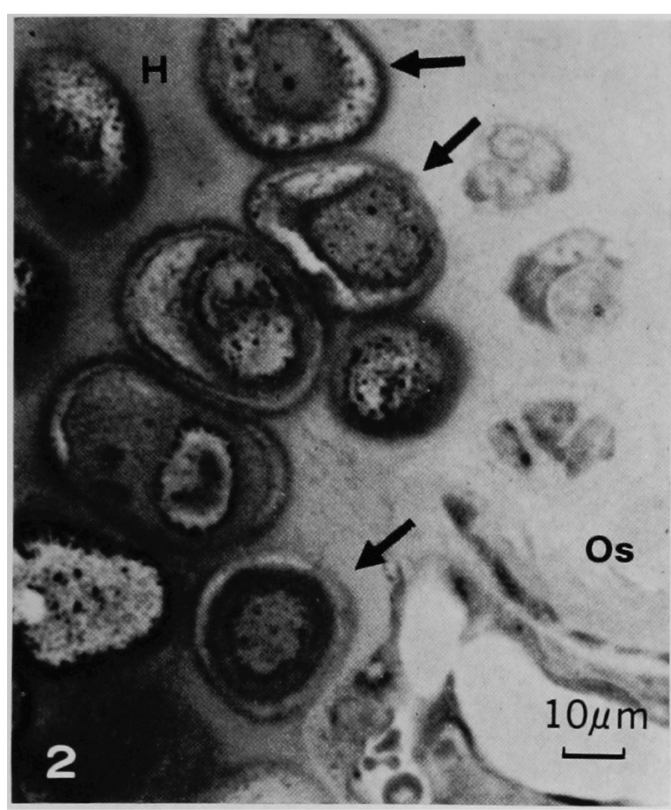

Fig. 2 Sr group: Transitional area between hypertrophic cell zone $(\mathrm{H})$ and osteoid tissue (Os). Some hypertrophic chondrocytes (arrows) do not show degenerative appearances. Semithin section, toluidine blue. $\times 650$ of these cells could be found within a lacuna. In the osteoid tissue in the neighbourhood of the hypertrophic cell zone, there were osteocyte-like cells with long cytoplasmic processes extending into the matrix (Fig. 7). These cells also had an accumulation of thick collagen fibrils with distinct D-periodicity around their cell body. Osteoblast-and osteocyte-like cells close beneath the perichondrium did not have such an accumulation of pericellular thick collagen fibrils. Their collagen fibrils were $68.2 \pm 10.6 \mathrm{~nm}$ in diameter, and almost round in cross-sectional profile.

By detailed observations of the area of ossification front in the control group, we could observe many hypertrophic chondrocytes which preserved a well organized nucleus and cytoplasm (Fig. 8). Mitotic cells were, however, not found in these cells. At the front of the vascular invasion, blood plasma leaked out from the capillary, and flowed into the lacuna of the hypertrophic chondrocyte through holes made by the dissolution of the calcified wall of the lacuna, as previously shown by Anderson and Parker'). The hypertrophic chondrocytes in these lacunae

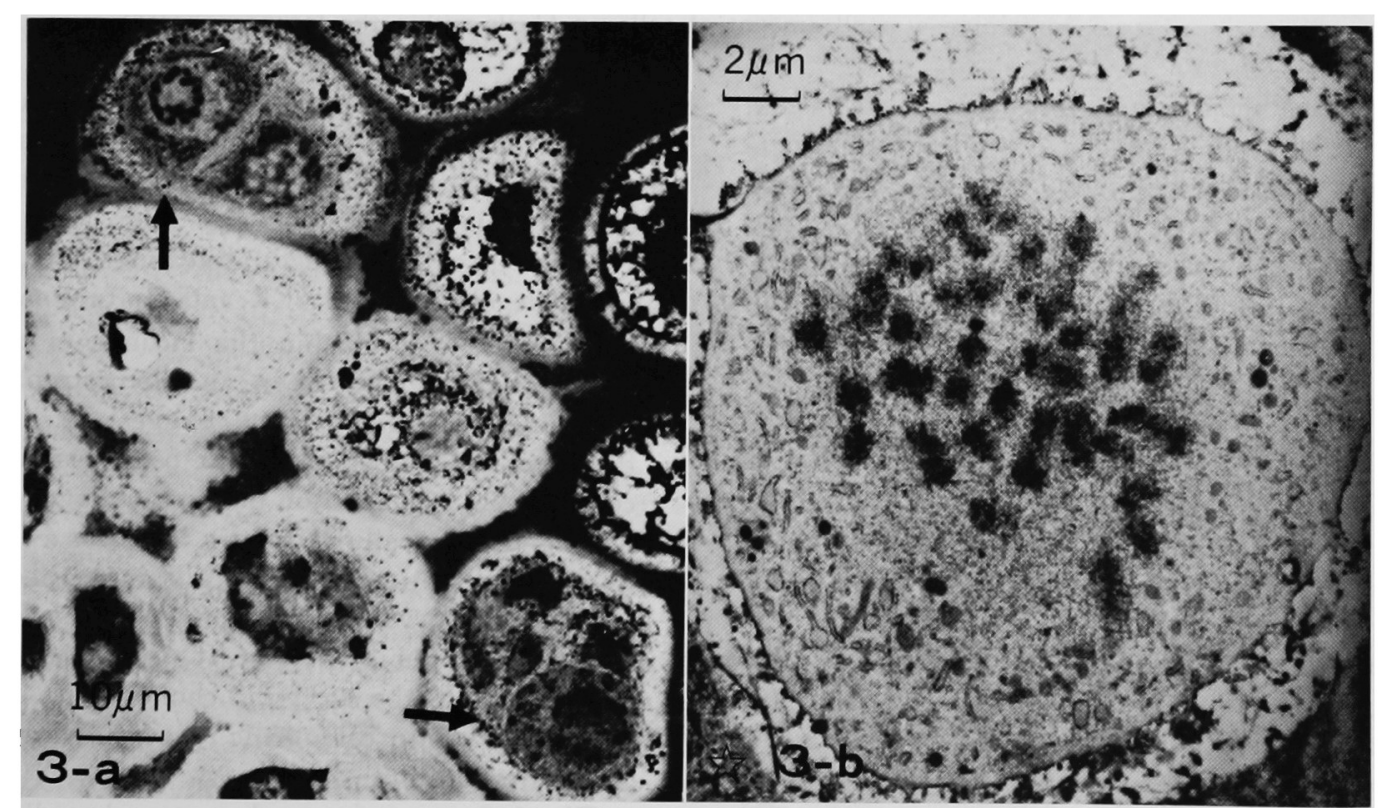

Fig. 3 Sr. group : a : Mitotic division of hypertrophic chondrocytes (arrows) in the transitional area. Semithin section, toluidine blue. $\times 880$

b: An electron micrograph of a mitotic division of hypertrophic chondrocyte. Cartilage matrix fibrils without bandings $(\xi) . \quad \times 4000$ 


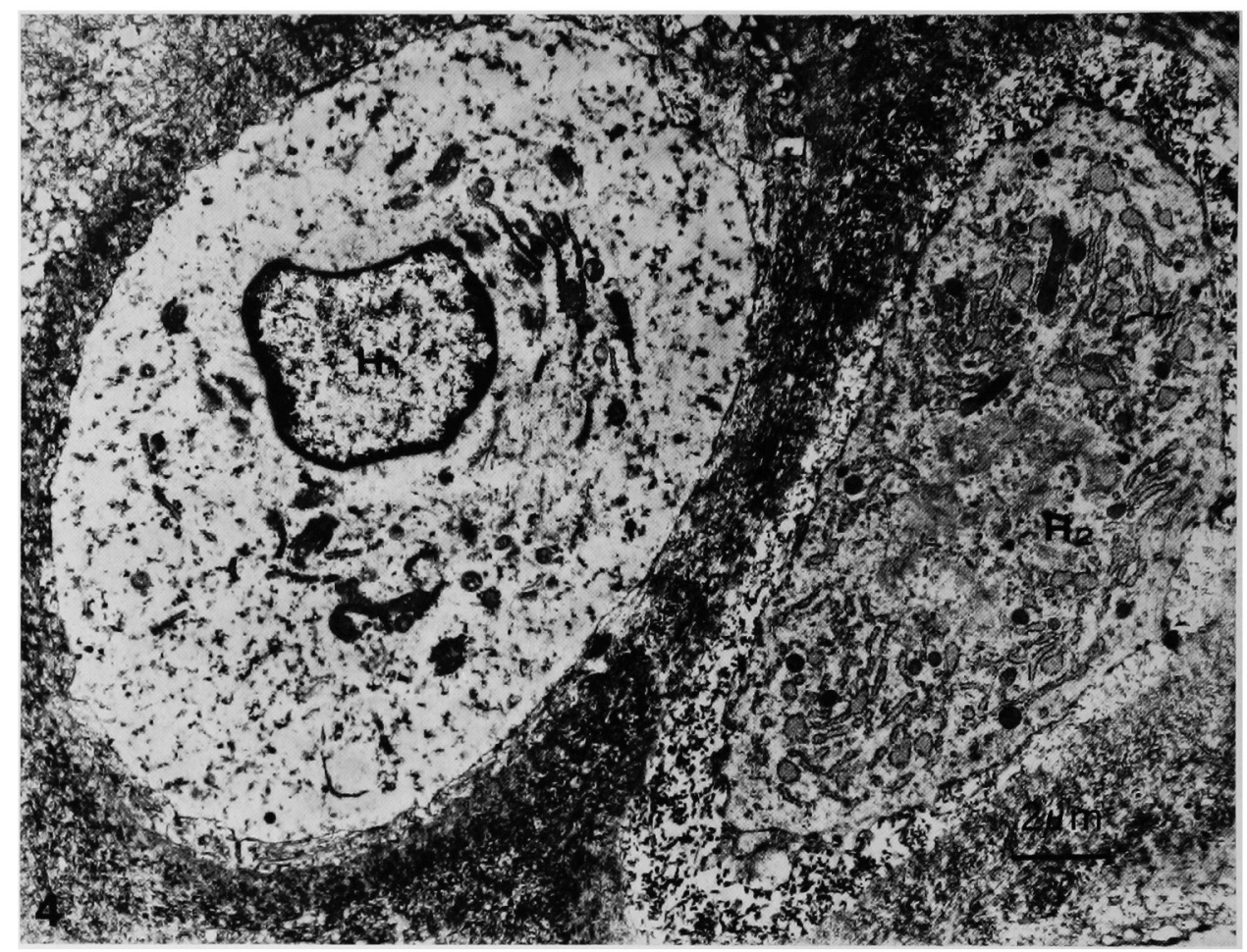

Fig. 4 Sr group: An electron micrograph of the transitional area. A hypertrophic chondrocyte $\left(\mathrm{H}_{1}\right)$ has a small amount of organelles. The other $\left(\mathrm{H}_{2}\right)$ shows abundant $\mathrm{rER}$ and prominent Golgi complex. Note a narrow extracellular space containing a small amount of collagen fibrils within the lacuna. $\times 5000$

were bathed in the infiltrated blood plasma, and showed a nucleus with a prominent nucleolus. The cytoplasm of these cells contained many small profiles of rER and glycogen areas. These cells would reasonably be expected to survive.

\section{Discussion}

The present study demonstrated mitotic cells in the peripheral regions of the hypertrophic cell zone of the mandibular condyle in experimentally induced strontium rickets. Since many cells in the mature cell zone were hypertrophied, it is unlikely that the mitotic cells are derived directly from maturing or more immature chondrocytes. The mitotic cells were present within the intact lacunae separated from the perivascular space of capillaries invaded from the perichondrium. Thus, they can not be the derivatives of undifferentiated mesenchymal cells associated with the capillaries. Therefore, only the hypertrophic chondrocytes can be the precursors of the mitotic cells. These findings substantiate that the survival of at least some hypertrophic chondrocytes can occur.

A series of ultrastructural features including a development of rER and Golgi complex in the cells within the lacunae in the transitional area between the hypertrophic cell zone and osteoid tissue, suggest a transformation of these cells into osteoblast-like cells. An accumulation of thick collagen fibrils in the pericellular matrix indicates a further differentiation of these cells into osteocyte-like cells, which are involved in the formation of osteoid tissue. It is suggested, therefore, that the surviving chondrocytes can differentiate into osteogenic type cells directly or after mitotic division.

The influence of strontium on mineralized tissues, known as strontium rickets, has been extensively investigated ${ }^{15-18)}$. Strontium has local effects on the cells involved in the end- 


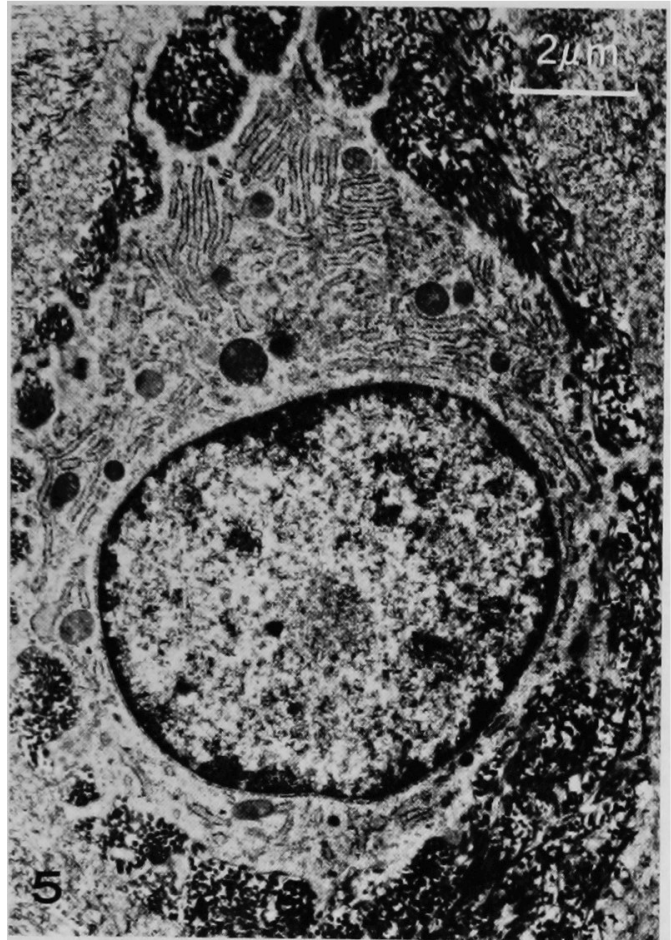

Fig. 5 Sr grcup: An csteoblast-like cell having an accumulation of thick collagen fibrils. $\times 6600$

ochondral ossification as well as on the mineralization of the matrix ${ }^{15,19,20)}$. Low calcification of the cartilage matrix may allow sufficient nutrients to reach the lacunae, allowing the hypertrophic chondrocytes to maintain their activity. Strontium might also influence directly the hypertrophic chondrocytes to divide mitotically. The cytological changes observed in the present study might, therefore, be specific to the administration of strontium. However, in the control group of the present study, the survival of hypertrophic chondrocytes was also confirmed.

The generally accepted concept for the fate of the hypertrophic chondrocyte was derived from a number of observations. $\mathrm{Hy}$ pertrophic cells generally showed degenerative features by conventional tissue fixation ${ }^{2,4,5}$. Mitotic figures and transitional stages from hypertrophic cells to osteogenic cells were not observed ${ }^{51}$. There was little uptake of ${ }^{3} \mathrm{H}$-thymidine by hypertrophic cells $\mathrm{s}^{1,3,21}$.

On the contrary, vitality of most hypertrophic chondrocytes has been demonstrated by

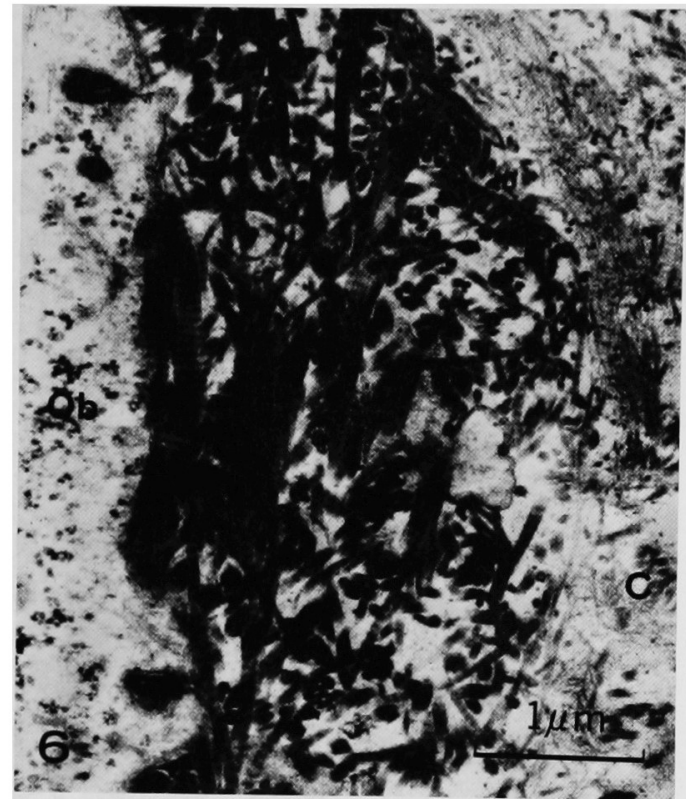

Fig. 6 Sr group : A portion of osteoblast-like cell $(\mathrm{Ob})$ and an extracellular space filled with thick collagen fibrils with distinct D-periodicity. $\mathrm{C}=$ cartilage matrix. $\times 17600$

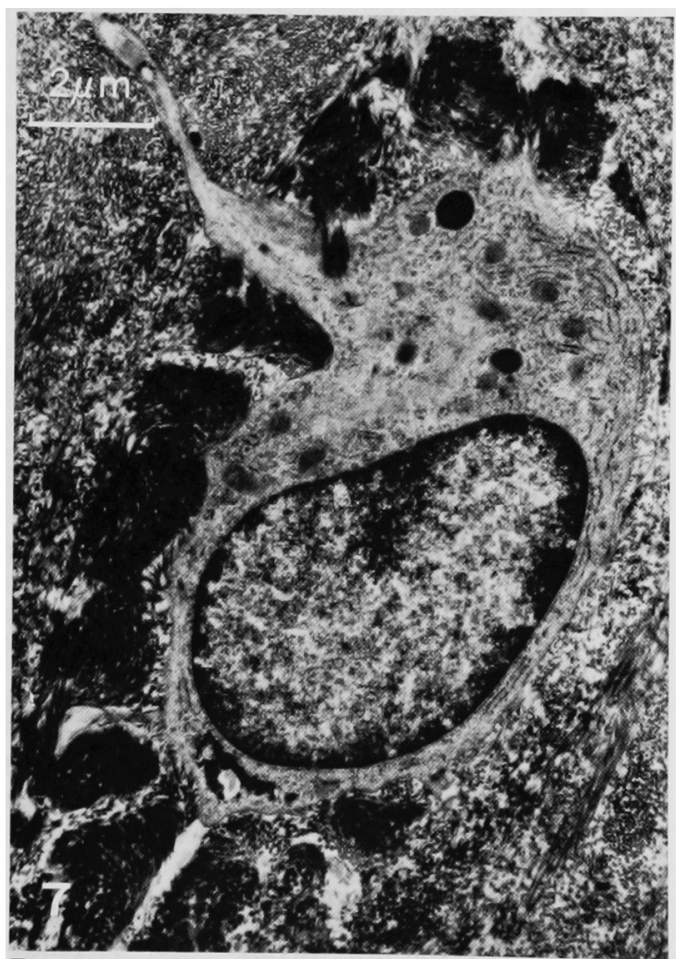

Fig. 7 Sr group: An osteocyte-like cell in the osteoid tissue neighbouring with the hypertrophic cell zone. $\times 6600$ 


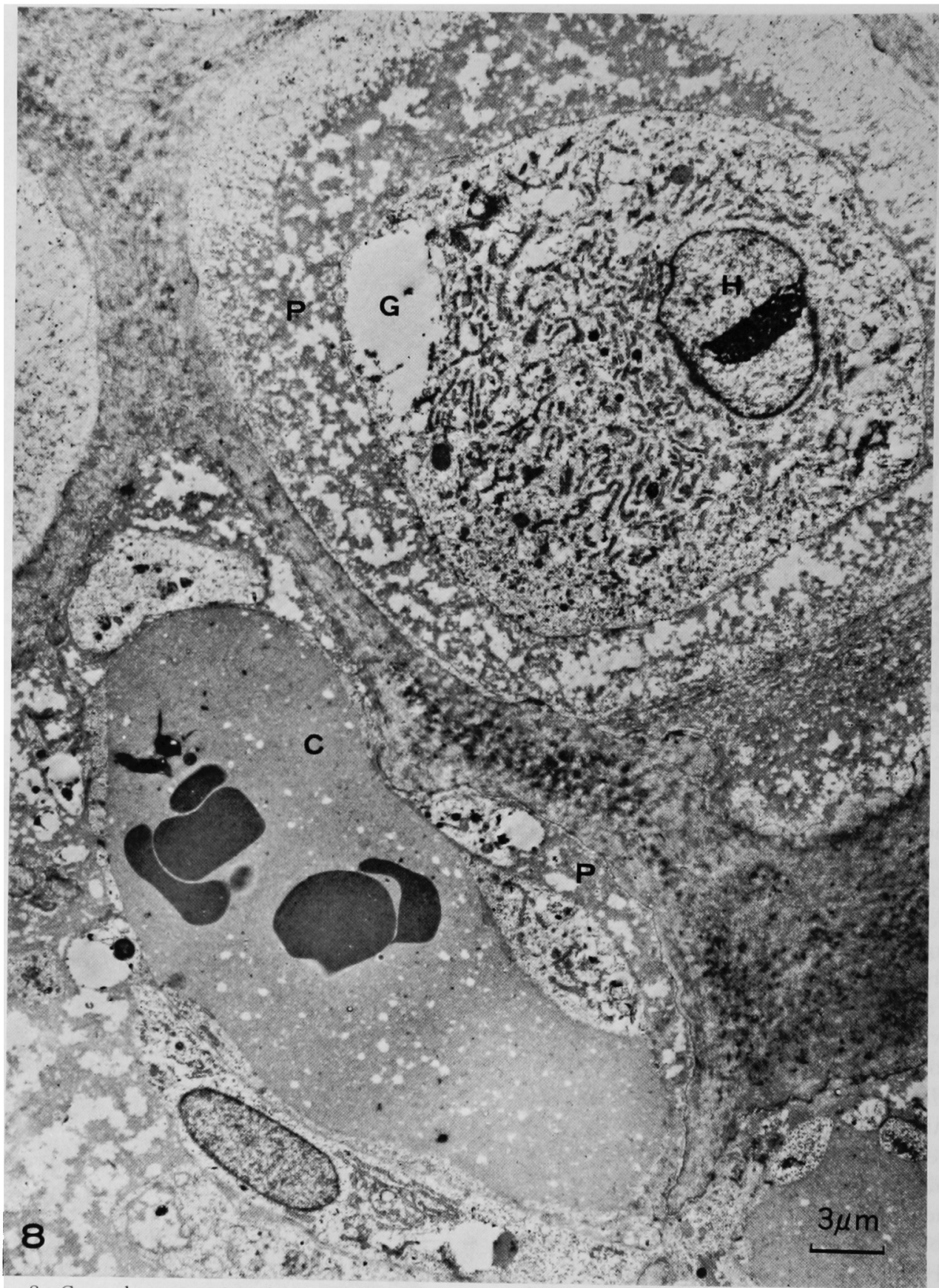

Fig. 8 Control group : An electron micrograph of the front of vascular invasion. A hypertrophic chondrocyte $(\mathrm{H})$ with well organized nucleus and cytoplasm is bathed in the blood plasma (P). $\mathrm{C}=$ the front of invading capirally. $\mathrm{G}=$ glycogen area. $\times 3300$

conventional and improved fixation techniques for electron microscopy $y^{9,14,22,23)}$. Autoradiographic studies in the rat rib showed uptake of ${ }^{3} \mathrm{H}$-thymidine by hypertrophic chon- drocytes ${ }^{24}$. With ${ }^{3} \mathrm{H}$-proline and ${ }^{35} \mathrm{~S}$-sulfate autoradiography, Silbermann and Frommer ${ }^{11,12}$ suggested that many chondrocytes in the mouse mandibular condyle advance thr- 
ough the calcified zone without dying. In agreement with these findings, we conclude that the survival of hypertrophic chondrocyte is a general phenomenon in the endochondral ossification in various sites.

The fate of the surviving hypertrophic chondrocytes is yet unclear in normal endoch. ondral ossification, where perivascular mesenchyme-derived osteoblasts play a main role in the osteogenesis ${ }^{25}$. The surviving chondrocytes, like those in strontium rickets, may redifferentiate after mitotic division or directly transform into osteoblasts to take part in the formation of new bone. We could not find, however, mitotic figures in those cells in the control group. Further studies are needed for the confirmation of these phenomena.

\section{Aknowledgments}

We would like to thank Prof. T. Oka (Department of Oral Surgery, School of Medicine, FujitaGakuen Health University), Prof. M. Nagayama (Department of Oral Surgery, School of Dentistry, Tokushima University), and Prof. A. Matsumoto (Department of Dental Pharmacology, School of Dentistry, Showa University) for their advice on this study.

抄録 : $\mathrm{Ca}$ 塩のかわりに $2.2 \% \mathrm{SrCO}_{3}$ を含んだ飼料をラットに与えたことによって下頡頭に Strontium Rickets が生じた。その主な形態学的変化は，下頡頭の Strontium Rickets の特徴である小さな下頻頭， 桩大した下頡枝, 肥大軟骨細胞層の増生, そして類骨組織の形成であった。光顕及び電顕で詳細に観察す ると肥大軟骨細胞層から類骨組織への移行領域に, 肥大軟骨細胞の分裂像がしばしば観察された。さら に, 同領域の小腔内の肥大軟骨細胞は, 類骨組織を形成する骨芽細胞様細胞, さらには骨細胞様細胞へと 発達していく一連の移行像を示した。これらの所見は Strontium Ricketsにおいて肥大軟骨細胞は変性 しないで，直接あるいは有采分裂後に骨基質形成細胞へ形質転換できることを強く示唆するものである。 一方, $1.5 \% \mathrm{CaCO}_{3}$ 含んだ通常食を与えた対照ラットの下頻頭においても，多くの肥大軟骨細胞は, 毛細血管の侵入によって軟骨小腔が侵食されても変性像を示さなかった。これらの生き残った軟骨細胞 のその後の運命は，未だ明らかではないが，今回の我々の所見は，軟骨内骨化の過程で肥大軟骨細胞は すべて死滅するとの定説とは一致しない。

\section{References}

1) Kember, N. F.: Cell division in endochondral ossificaion. J. Bone Joint Surg [Br]. 42 : 824-839, 1960

2) Anderson, C. E. and Parker, J. : Invasion and resorption in enchodral ossification. An electron microscopic study. J. Bone Joint Surg $[A m] .48: 899-914,1966$.

3) Bentley, G. and Greer, R. B.: The fate of chondrocytes in endochondral ossification in the rabbit. J. Bone Joint surg $[\mathrm{Br}] .52$ : 571-577, 1970.

4) Brighton, C. T., Sugioka, Y. and Hunt, R. M. : Cytoplasmic structures of epiphyseal plate chondrocytes. Quantitative evaluation using electron micrographs of rat costochondral junctions with special reference to the fate of hypertrophic cells. J. Bone Joint Surg [Am]. 55 : 771-784, 1973.

5) Crissman, R. S. and Low, F. N. : A study of fine structural changes in the cartilageto-bone transition within the developing chick vertebra. Am. J. Anat. $140: 451-470$,
1974.

6) Hanaoka, H.: The fate of Hypertrophic chondrocytes of the epiphyseal plate. J. Bone Joint Surg [Am]. 58: 226-229, 1976.

7) Crelin, E. S. and Koch, W. E. : An autoradiographic study of chendrocyte transformation into chondroclasts and osteocytes during bone formation in vitro. Anat. Rec. 158 : 473 $-484,1967$.

8) Lutf, A. M.: The fate of chondrocytes during cartilage erosion in the growing tibia in the domestic fowl (Gallus domesticus). Acta. Anat. 79 : 27-35, 1971.

9) Holtrop, M. E. : The ultrastructure of the epiphyseal plate. II. The hypertrophic chondrocyte. Calcif. Tissue Res. $9: 140-151$, 1972.

10) Kahn, A. J. and Simmouns, D. J. : Chondrocyte-to-osteocyte transformation in graftes of perichondrium-free epiphyseal cartilage. Clin. Orthop. 129 : 299-304, 1977.

11) Silbermann, M. and Frommer, J. : The nature of endochondral ossification in the mandibular condyle of the mouse. Anat. Rec. 
$172: 659-668,1972$.

12) Silbermann, M. and Frommer, J. : Vitality of chondrocytes in the mandibular condyle as revealed by collagen formation. An autoradiographic study with ${ }^{3} \mathrm{H}$-proline. Am. J. Anat. 135 : 359-370, 1972.

13) Silbermann, M. and Frommer, J. : Further evidence for the vitality of chondrocytes in the mandibular condyle as revealed by ${ }^{35} \mathrm{~S}$ sulfate autoradiography. Anat. Rec. 174 : 503-512, (1972).

14) Silbermann, M. and Frommer, J.: Ultrastructure of developing cartilage in the mandibular condyle of the mouse. Acta. Anat. 90 : 330-346, 1974.

15) Nagayama, M., Saburi, N., Oka, T. ; and Matsumoto, A.: Endochondral ossification of the condyle in rats on a strontium or low-calcium diet. J. Oral Maxillofac. Surg. 43 : 693-703, 1985.

16) Storey, E. : Strontium "Rickets": Bone, calcium, and strontium change. Aust. Ann. Med. 10 : 213-222, 1961.

17) Yeager, J. A.: Fine structure of the matrix of the response in rat incisor dentin to injected strontium. J. Dent. Res. 42 : 1178-1182, 1963.

18) Reinholt, F. P., Hjerpe, A., Jansson, K., and Engfeldt, B.: Stereological studies on the epiphyseal growth plate in strontiuminduced rickets, J. Bone Joint surg [Am].
66 : 1274-1280, 1984.

19) Engfeldt, B. and Hjertquist, S.-O.: The effect of strontium administration on bone and teeth of rats maintained on diets with different calcium contents. Virchows Arch. Abt. A Path. Anat. 346 : 330-344, 1969.

20) Matsumoto, A. : Effect of strontium on the epiphyseal cartilage plate of rat tibiaeHistological and radiographic studies. Jpn J. Pharmacol. 26 : 675-681, 1976.

21) Young, R. W. : Cell proliferation and specialization during endochondral osteogenesis in young rats. J. Cell Biol. $14: 357-370$, 1962.

22) Oi, T. and Utsumi, N. : Ultrastructure of hypertrophic chondrocytes of rat mandibular condyles using lanthanum-containing fixatives. Arch. Oral Biol. 25 : 77-81, 1980.

23) Hunziker, E. B., Herrmann, W., Schenk, R. K., Mueller, M. and Moor, H.: Cartilage ultrastructure after high pressure freezing, freeze substitution, and low temperature embedding. J. Cell Biol. 98 : 267-276, 1984.

24) Shimomura, Y., Wezeman, F. H. and Ray, R. D.: The growth cartilage plate of the rat rib: Cellular differentiation. Clin. Orthop. $90: 246-254,1973$.

25) Bloom, and Fawcett, D. W.: A Textbook of histology, 10 th ed, Philadelphia, W. B. Saunders Co., pp. 271-273, 1975. 